\title{
Urban flood risks, impacts, and management in Nigeria
}

Brian Lucas

Research consultant

25 January 2021

\section{Question}

Please provide an overview of urban flooding impact, risk factors, and management and mitigation measures in Lagos and other cities in Nigeria.

\section{Contents}

\author{
1. Summary \\ 2. Lagos (Lagos State) \\ 3. Calabar (Cross River State) \\ 4. Makurdi (Benue State) \\ 5. Ibadan (Oyo State) \\ Expert contacts \\ References
}

The K4D helpdesk service provides brief summaries of current research, evidence, and lessons learned. Helpdesk reports are not rigorous or systematic reviews; they are intended to provide an introduction to the most important evidence related to a research question. They draw on a rapid deskbased review of published literature and consultation with subject specialists.

Helpdesk reports are commissioned by the UK Foreign, Commonwealth, and Development Office and other Government departments, but the views and opinions expressed do not necessarily reflect those of FCDO, the UK Government, K4D or any other contributing organisation. For further information, please contact helpdesk@k4d.info. 


\section{Summary}

Flooding is a common problem every year in many cities across Nigeria, but the impacts of flooding are poorly documented. There is no consistent set of statistics at a national or subnational level that can be used to compare the impacts of flooding across cities, and reports that focus on particular flood events are often incomplete (Lamond, Adekola, Adelekan, Eze, \& Ujoh, 2019 , p. 2) or describe impacts without quantifying their magnitude.

In Lagos ${ }^{1}$, the total economic losses due to flooding across the state have been estimated at USD 4 billion per year, which is $4.1 \%$ of the state's GDP or $1.0 \%$ of national GDP (Croitoru, Miranda, Khattabi, \& Lee, 2020, pp. ix-x). In Ibadan (Oyo State), average annual losses due to flooding have been estimated at USD 105.3 million per year (World Bank, 2014, p. 86). Between 2000 and 2015, floods are estimated to have killed 129 people, destroyed 3,102 homes, and damaged 9,112 homes (Adelekan, 2020, pp. 225, 227). In Calabar (Cross River State), and Makurdi (Benue State), flooding is an annual occurrence but very little information is available about the impacts of flooding, apart from limited evidence about the impacts of a few specific flood events.

Most of the information available about the impacts of flooding in Nigerian cities is not disaggregated by gender, but it is well established worldwide that women and girls are disproportionately vulnerable to the effects of natural hazards (Bogdan, McPherlain, \& Yoon, 2019; Utz, 2017, p. 90). One study in Lagos confirms this finding in the Nigerian context, showing that low-income women experienced more severe impacts and slower recovery in relation to flooding compared with other women and men (Ajibade, McBean, \& Bezner-Kerr, 2013, p. 1714).

The principal factors ${ }^{2}$ contributing to flood risk are consistent across the cities examined in this report:

- Uncontrolled urban growth: Although cities and states have regulations intended to prevent construction on floodplains and drainage channels, authorities struggle to enforce these regulations, and construction in flood-prone areas takes place across Nigeria.

- Inadequate and poorly-maintained drainage systems: All of the cities suffer from drainage systems that do not cover the entire urban area, lack sufficient capacity to handle current rainfall volumes, and are prone to being blocked by sediment and solid waste.

- Solid waste management practices: It is common for people to dispose of solid wastes in drainage channels, which leads to widespread problems of blocked drains.

- Weaknesses in institutional capacity and coordination: In all cities in Nigeria, a multiplicity of federal, state, and local agencies have various responsibilities relevant to

\footnotetext{
${ }^{1}$ The cities mentioned in this report were chosen based on the priorities of the team requesting the research and on the availability of published information; they do not necessarily represent the cities in Nigeria most affected by flooding. 2 This report focuses on anthropogenic risk factors. Factors such as climate change trends for each city are not
considered.
} 
flood risk management, but roles and responsibilities are often unclear, coordination among agencies is poor, and the capacities of different agencies are often weak.

- Early warning systems and public awareness: Local capacities for predicting floods and communicating warnings to the public are often weak, and residents often lack information about effective ways to prepare for floods.

The evidence base for flood impacts, risks, and mitigation efforts at the city level in Nigeria is limited, and much of the information available is low quality, inconsistent, or outdated. Many rely on surveys of city residents rather than objective empirical data, and some of these surveys appear to be poorly designed. A significant number of the academic publications available have been published in non-mainstream journals without the usual level of academic peer review. Recent information is scarce, and a significant amount of the available evidence dates from 2011 and 2012, which coincides with an episode of nationwide flooding that was among the worst in Nigeria's history. These observations are consistent with assessments of evidence on flood risk management from other countries across sub-Saharan Africa, where data on disaster losses have been described as 'too sparse to understand or make any reasonable connection or build trends to support flood management' (Osuteye, 2017, cited in Lamond et al., 2019, p. 2).

\section{Lagos (Lagos State)}

Lagos is the second largest megacity in Africa after Cairo, and the economic hub of Nigeria, contributing about $30 \%$ of national GDP and $62 \%$ of national non-oil sector GDP (Adelekan, 2016, p. 256). The population of Lagos is estimated as 13.4 million as of 2020 (Lagos State Government, 2021); it is densely populated, growing rapidly, and a large proportion of the population is poor and lives in communities with limited infrastructure or in informal settlements (Adelekan, 2016, p. 257; Atufu \& Holt, 2018, p. 82).

Flooding has long been an issue of increasing severity in Lagos. Flooding has been reported in the city since at least 1947, was described as widespread in the 1970s, and is now an annual occurrence (Ayoade \& Akintola, 1980, cited in Adelekan \& Asiyanbi, 2016, p. 449; Atufu \& Holt, 2018, p. 82). A survey by the Lagos State Government in 2016 found that $19 \%$ of respondents had experienced flooding within the past year (Lagos Bureau of Statistics, 2016, p. 329). Residents perceive flooding as the second most important hazard in the city, after crime (Adelekan \& Asiyanbi, 2016, p. 464).

\section{Impacts of flooding}

There is a lack of recent, high-quality information on the nature and magnitude of the impacts of flooding in Lagos. Many studies identify the types of impacts that affect the city, but very few quantify these impacts. Even for major flood events, it is common that 'only journalistic and nonquantitative evidence is available' and for minor floods (which are more frequent) it is often the case that no data at all are available (Nkwunonwo, Whitworth, \& Baily, 2016, p. 350).

A World Bank study published in 2020 estimated the total economic cost of environmental damage in the coastal zones of Cross River, Delta and Lagos States due to flooding. While Cross River and Delta States include both rural and urban areas, Lagos State is not much larger than Lagos city, so figures for the state may be indicative of flood damage in the city. The study 
estimates that flood damage ${ }^{3}$ in Lagos State amounts to a total economic cost of USD 3.992 billion per year (Table 1), which is $4.1 \%$ of the state's GDP or $1.0 \%$ of national GDP (Croitoru et al., 2020, pp. ix-x).

Table 1: Economic cost of flooding in Lagos State

\begin{tabular}{lr}
\hline & $\begin{array}{r}\text { Annual economic cost } \\
\text { USD million }\end{array}$ \\
\hline Damage due to fluvial floods & 3,835 \\
\hline Damage due to pluvial floods & 103 \\
\hline Mortality ${ }^{4}$ due to pluvial and fluvial floods & 55 \\
\hline Total damage due to floods & 3,992 \\
\hline
\end{tabular}

Source: Croitoru et al., 2020, p. 40, licensed under CC BY 3.0 IGO

Several surveys of Lagos residents have attempted to understand the impacts of flooding, but without being able to aggregate results to estimate overall impacts on the population. One study in six communities across Lagos in 2005 found that $72 \%$ of residents and $39 \%$ of businesses (mostly small enterprises such as artisans and retail traders) had suffered damage due to flooding, with most reporting losses on multiple occasions (Table 2 and See: Table 3) (Odunuga, Oyebande, \& Omojola, 2012, p. 90).

Table 2: Losses suffered by households in individual flood events in Lagos (2005)

\begin{tabular}{|c|c|c|c|}
\hline $\begin{array}{l}\text { Monetary value of } \\
\text { losses (USD)* }\end{array}$ & $\begin{array}{l}\text { Percentage of } \\
\text { respondents }\end{array}$ & $\begin{array}{l}\text { Number of times } \\
\text { losses have been } \\
\text { experienced }\end{array}$ & $\begin{array}{l}\text { Percentage of } \\
\text { respondents }\end{array}$ \\
\hline No/negligible losses** & $25.0 \%$ & Never & $25.0 \%$ \\
\hline $85-170$ & $38.6 \%$ & Once & $0.6 \%$ \\
\hline $170-424^{* * *}$ & $19.4 \%$ & 2 to 5 times & $30.7 \%$ \\
\hline $424-847$ & $10.0 \%$ & 6 to 10 times & $19.1 \%$ \\
\hline $848-4,237$ & $2.8 \%$ & More than 10 times & $21.9 \%$ \\
\hline $\begin{array}{l}\text { No response / don't } \\
\text { know }\end{array}$ & $4.2 \%$ & $\begin{array}{l}\text { No response / could } \\
\text { not remember }\end{array}$ & $2.5 \%$ \\
\hline
\end{tabular}

* Figures rounded to the nearest dollar from the source publication.

** The source publication does not give figures for losses between USD 0 and 85 , but based on the text, this appears to correspond to the proportion of respondents (25\%) who answered 'never' to the question about frequency of losses.

*** The median monthly income of respondents falls within this range: more than half of the population surveyed earn less than USD 339 per month.

Source: Odunuga et al., 2012, p. 90, https://silo.tips/download/social-economic-indicators-and-public-perception-on-urbanflooding-in-lagos-nige

\footnotetext{
${ }^{3}$ The analysis did not consider coastal flooding, due to data limitations (Croitoru et al., 2020, p. 37).

${ }^{4}$ The cost of mortality was estimated based on the number of deaths due to flooding and the 'value of a statistical life', a value estimated based on a society's willingness to pay to avoid the risk of death; a value of USD 167,400 was used, following World Bank guidelines (Croitoru et al., 2020, p. 10).
} 
See: Table 3: Losses suffered by businesses in individual flood events in Lagos (2005), Source: Odunuga et al., 2012, p. 91, https://silo.tips/download/social-economic-indicatorsand-public-perception-on-urban-flooding-in-lagos-nige

Another survey conducted in five local government areas across Lagos found that around onethird of respondents had suffered some sort of impacts from flooding (See: Table 4) (Atufu \& Holt, 2018, p. 87).

See: Table 4: Impacts of flooding experienced by residents of five local government areas across Lagos, Source: Atufu \& Holt, 2018, p. 87, https://www.witpress.com/elibrary/wittransactions-on-the-built-environment/184/36659

A study of the impact of the floods of July 2011 on women in different neighbourhoods of Lagos found that while high-income women did not experience significantly different impacts from their husbands, low-income women experienced more severe impacts and slower recovery compared with other women and men (Ajibade et al., 2013, p. 1714). Flooding of homes affected women more severely than men because of their home-based duties such as childcare, food preparation, and cleaning; because they often operated small home-based businesses; and because of greater difficulties related to loss of privacy and access to sanitation facilities in disaster conditions (Ajibade et al., 2013, pp. 1720-1721).

Other studies describe the following impacts of flooding in Lagos:

- $81 \%$ of respondents to a survey reported increased transportation costs and breakdown of vehicles making travel difficult (Odunuga et al., 2012, p. 91).

- More than half of all respondents to a Lagos-wide survey had experienced property damage worth more than NGN 52,000 (USD 330), which is more than one month's income for three-quarters of the respondents (Adelekan \& Asiyanbi, 2016, pp. 451-455).

- Across much of Lagos, drainage channels carrying raw sewage and solid waste overflow during floods, contaminating water sources and spreading waterborne diseases (Adelekan \& Asiyanbi, 2016, p. 464), but the prevalence of diseases was not estimated.

- In a survey of residents of four communities across Lagos, $91 \%$ of respondents described 'recurrent visits to health centres because of ill-health and an increase in medical expenses as a major outcome of floods' (Adelekan, 2010, p. 446).

- In 2010, flooding in Ikorodu in north-eastern Lagos resulted in 'widespread losses and damages' (Adelekan \& Asiyanbi, 2016, p. 449) and displaced several thousand residents, of whom 1,765 were temporarily housed for ten months by the Lagos State government (Adelekan, 2016, p. 261; Adelekan \& Asiyanbi, 2016, p. 449).

- Flooding in July 2011, triggered by heavy rains, was reported to have resulted in between 17 and 25 deaths (although one report mentions 'over one hundred' deaths) and the displacement of approximately 5,000 people (although an IFRC report cites 5,393 households affected, and it appears that some reports may have confused these figures), 
with damage estimated at between USD 200 and 320 million (Adelekan, 2016, p. 257; Adelekan \& Asiyanbi, 2016, p. 449; Ajibade et al., 2013, p. 2; IFRC, 2011, pp. 1-2).

- In 2012, seven people were reported to have died in Lagos as a result of flooding (Adelekan \& Asiyanbi, 2016, p. 449), 430 people were affected, and an unknown number of houses were destroyed (Federal Government of Nigeria, 2013, p. 125).

- In September, 2020, flooding in three local government areas within Lagos (Apapa, Mushin and Surulere) was reported to have displaced 15,385 people, with the National Emergency Management Agency providing food and building supplies to assist residents (National Emergency Management Agency, 2020, p. 26).

Interestingly, $7 \%$ of respondents to one survey stated that they were able to extract an economic benefit from flooding. They did this by assisting (for a fee) motorists whose vehicles broke down in their neighbourhood. On days when roads are flooded in Idi-Araba near the Lagos University Teaching Hospital, these people, described in the report as 'street urchins', earn up to USD 14 (NGN 2,000) 'by helping those in need of assistance' (Odunuga et al., 2012, p. 90).

\section{Risk factors and mitigation efforts}

\section{Geography and climate}

Lagos is located on the shore of the Atlantic Ocean on low-lying terrain less than two metres above sea level, with a network of rivers making it susceptible to both coastal and fluvial flooding (Adelekan, 2016, p. 257; Sojobi, Balogun, \& Salami, 2016, p. 3). The relatively flat terrain with slopes typically between $1 \%$ and $4 \%$ means that runoff is relatively slow to drain away, increasing flood risk (Atufu \& Holt, 2018, p. 82; Sojobi et al., 2016, p. 3). Since 2000, the frequency, severity, and spatial extent of flooding caused by rainfall and storm surges has increased, with coastal and mainland areas of the city experiencing increased flooding during the rainy season (Adelekan, 2016, p. 257; Adelekan \& Asiyanbi, 2016, pp. 448-449). Sea level rise associated with climate change, estimated as potentially reaching $59 \mathrm{~cm}$ by 2100 , is likely to worsen problems of coastal inundation, flooding, and intrusion of sea water into freshwater sources and ecosystems in Lagos (Ebele \& Emodi, 2016, and Fashae \& Onafeso, 2011, cited in Haider, 2019, pp. 8, 14).

\section{Urban planning}

The inability of city authorities to control urban development is a major factor contributing to increased exposure to flood hazards and increased risk. Existing regulations require minimum setbacks from water bodies and drainage channels, the state government provides land to developers at rates intended to discourage development on marginal lands, and the government has mandated the discontinuation of development in areas liable to flooding and wetlands (Adelekan, 2016, p. 259). However, despite these incentives and regulations, large numbers of buildings and other structures have been built and are still being built on drainage paths, floodplains, and close to the coast (Adelekan, 2016, p. 259; Atufu \& Holt, 2018, pp. 88-89). The high cost of land and housing lead people to settle in informal settlements and in undesirable, swampy and low-lying areas (Oladokun \& Proverbs, 2016, p. 491). 
There have been calls for more attention to the enforcement of urban planning guidelines, urban development, and building control (Adelekan \& Asiyanbi, 2016, p. 263). The state government has undertaken demolition of buildings located on drainage paths in some cases, including in flood-prone communities of Agege and ljeshatedo in 2011 and ljora-Badia (2010, 2012 and 2013) (Adelekan, 2016, p. 258) but details of these exercises have not been obtained.

\section{Structural measures including drainage systems}

Structural measures for flood risk management in Lagos have included constructing drainage channels, breakwaters, and revetments ${ }^{5}$, as well as dredging and channelising waterways (Adelekan \& Asiyanbi, 2016, pp. 258-259). The ongoing construction of an $8.5 \mathrm{~km}$ revetment known as 'the Great Wall of Lagos' is intended to protect Victoria Island from flooding and erosion and to contain a new luxury development called Eko Atlantic City which is currently being built on a new peninsula created from sand raised from the ocean floor (Akinwotu, 2019; Eko Atlantic, n.d.). The project has, however, been challenged for possibly altering ocean currents and causing erosion problems in other areas along the coast (Akinwotu, 2019).

Drainage systems within the city are seen by many as being inadequate (Olanrewaju, Chitakira, Olanrewaju, \& Louw, 2019 , p. 2). One report indicates that only $45 \%$ of Lagos is covered by a drainage system, and that less than $30 \%$ of drains are maintained (Nwigwe \& Emberga, 2014, and Aderogba, 2012, cited in Sojobi et al., 2016, p. 3). Another survey of residents in five communities in Lagos found that $57 \%$ of respondents stated that there were drainage facilities in their neighbourhoods but that $95 \%$ of these are open drains, which are easily blocked and are liable to overflow during flooding, and $75 \%$ of respondents noted that drains in their neighbourhoods were in fact already blocked (Olokesusi, Olorunfemi, Onwuemele, \& Oke, 2015, p. 219). A survey by the Lagos State government in 2016 found that $68 \%$ of respondents claimed that their streets had drains, which included $23 \%$ covered drains, $73 \%$ uncovered, and $4 \%$ earth drains (Lagos Bureau of Statistics, 2016, p. 17).

\section{Solid waste management}

Inadequate solid waste management is a significant contributor to blocking drainage systems and increasing flood risk in Lagos (Adelekan, 2016, pp. 257, 260; Adelekan \& Asiyanbi, 2016, p. 260; Atufu \& Holt, 2018, p. 86,88; Nkwunonwo et al., 2016, p. 351; Sojobi et al., 2016, pp. 555556). Household waste is routinely dumped in drainage channels, or in streets and local refuse dumps where it is eventually washed into drainage channels (Olokesusi et al., 2015, pp. 217218). A recent addition to the problem is the widespread consumption of 'pure water' or 'sachet water', sold in polythene sachets which are a major source of plastic waste as they often end up accumulating in drains and blocking them (Nkwunonwo et al., 2016, pp. 353-354).

There appears to be good public awareness of the problem of waste disposal in drains, but people lack alternatives. In one survey carried out in six areas in Lagos in $2005,95 \%$ of respondents stated that blocked drains contributed to flooding, but when asked why people still dump refuse in drainage channels, $40 \%$ did not know, $15 \%$ mentioned a lack of a government

\footnotetext{
${ }^{5}$ Sloping structures, typically made of boulders or concrete, that protect shorelines from flood damage and erosion.
} 
waste collection service, $10 \%$ said that people avoided crossing major roads to dump refuse in alternative locations, and $25 \%$ referred to filling swamp areas for reclamation (Odunuga et al., 2012, p. 92). In general, people with lower incomes are more likely to dump refuse in drainage systems (Odunuga et al., 2012, p. 93). In a survey by the Lagos State Government in 2016, 90\% of respondents said that drainage channels are not to be used for dumping refuse, and only $11 \%$ admitted to doing so themselves, but when asked about neighbours' activities, $18 \%$ said that neighbours regularly dump refuse into drainage channels, 35\% said this happened occasionally, and $14 \%$ said that such dumping is 'sometimes inevitable' (Lagos Bureau of Statistics, 2016, pp. $332,336,341)$. Waste bins are provided but not regularly collected by the Lagos State Waste Management Authority (Atufu \& Holt, 2018, p. 88).

Community efforts to clear blocked drains have been undertaken, but often fail because of a lack of ability to dispose of the waste excavated from the drains; it is dumped by the side of the channels or used to fill depressions in road surfaces, and ends up simply being washed back into the drainage system (Atufu \& Holt, 2018, p. 88; Odunuga et al., 2012, p. 93). The city's Office of Drainage Services attempts to clear major drainage channels at the beginning of the rainy season (Adelekan \& Asiyanbi, 2016, p. 464) but $82 \%$ of residents say that their local drains are cleaned by community members (Lagos Bureau of Statistics, 2016, p. 328). The National Orientation Agency uses television and radio to raise awareness, but the impact is limited and very short lived (Atufu \& Holt, 2018, p. 88).

\section{Ecosystem-based interventions}

Ecosystem-based interventions have received little attention in Lagos. Urban master plans developed by the Lagos State government call for ecosystem-based measures in the Lagos Mainland Central area including vegetated banks capable of absorbing floodwater instead of or in addition to concrete flood defence walls, the use of porous paving material such as self-binding gravel to allow rain and floodwater to infiltrate into the soil, and adopting green roof technology to reduce the burden on the storm water and sewerage system (Adelekan, 2016, p. 262) but the extent of adoption of these policies is not known. One paper argues that urban landscaping projects can discourage the dumping of solid waste in public areas and help control the blocking of drains by solid waste, and highlights examples of parks and gardens created within Lagos (Ogunsote, Adedeji, \& Ogunsote, 2011), but does not provide empirical evidence about the potential contribution to flood risk management.

\section{Institutional capacity and coordination}

Several experts point out weaknesses in the capacities of the government agencies that have responsibilities for flood risk management in Lagos. Multiple agencies and levels of government are involved in activities related to flood risk management, but coordination among them is weak, and roles, responsibilities, and lines of authority are not clearly defined (Nkwunonwo et al., 2016, pp. 358-359; Olanrewaju et al., 2019, p. 6). It is widely acknowledged that capacity to enforce existing laws and policies needs to be significantly strengthened (Atufu \& Holt, 2018, p. 89). In some cases, initiatives have focused on the city core, neglecting outlying areas, and 'projects often suffer when new governments abandon uncompleted projects of their predecessors' (Nkwunonwo et al., 2016, p. 358). The State government has also been criticised for failing to learn from past floods, although it has recently begun to 'develop substantive flood management 
strategies, collaborate locally and globally and learn from other global coastal cities on flood management' (Adelekan, 2016, p. 262).

\section{Early warning systems and flood risk modelling}

Existing systems for modelling flood risk and issuing flood warnings are limited by a lack of access to high-quality and high-resolution data and models for analysing urban topography, land cover, social and economic vulnerability, and the relationship between flood flows and damage, and by a lack of local expertise and capacity to carry out this kind of modelling (Adelekan \& Asiyanbi, 2016, p. 262; Nkwunonwo et al., 2016, pp. 357-364; Ouikotan, van der Kwast, Mynett, \& Afouda, 2017, p. 8). Recent improvements in seasonal rainfall forecasts by the Nigerian Meteorological Agency have the potential to support flood prediction and early warning, but there is also a need to improve hydrological modelling capacity, so that rainfall forecasts can be used to predict runoff and flood levels and produce more relevant flood forecasts (Adelekan, 2016, pp. 260-262). For the best predictions of flood occurrence and impact, bespoke flood models for simulating flood hazard specifically in Lagos will need to be developed and calibrated against onthe-ground surveys of flood damage (Nkwunonwo et al., 2016, pp. 362-365).

There is also a need to improve communication of flood warnings and awareness of flood risks among the public (Adelekan, 2016, p. 262). Lagos City authorities undertake flood awareness campaigns annually, alongside the National Emergency Management Agency, National Orientation Agency, and National Disaster Management Framework (Adelekan \& Asiyanbi, 2016, pp. 259-260; Olanrewaju et al., 2019, p. 6). Nonetheless, 'many residents do not have the knowledge to enable them prepare and address the possible consequences of flood hazards' and improving risk communication may help strengthen residents' capacity to cope with flood risk (Adelekan \& Asiyanbi, 2016, p. 448).

Residents of Lagos often do not respond actively to current flood warnings, perceiving them with indifference or even suspicion. One household survey questionnaire across five communities in Lagos in 2011 found that $77 \%$ of respondents were aware of flood warnings issued by the state government, but half of the respondents stated that they had not made any emergency plans (Olokesusi et al., 2015, pp. 211-215).

Warnings that recommend evacuation are often ignored because residents have no alternative accommodations and limited financial resources (Adelekan, 2016, p. 260). Some residents suspect that flood warnings are an attempt to evict them and acquire their land, citing the example of Maroko in 1990 when more than 300,000 residents were moved to make way for improvements and reallocation of land (Atufu \& Holt, 2018, p. 87; Olokesusi et al., 2015, p. 215). Residents were also suspicious of arrangements that might be made to house evacuees, describing the relocation camp that the government opened in Agbowa for victims of flooding in 2010 as 'more or less like a psychiatric home' (Olokesusi et al., 2015, p. 215). Others simply argue that flooding is regular and inevitable, that the cost of relocating is beyond their means, that as property owners they could not abandon their homes, or that past warnings had led to nothing and the flooding would not have any serious effects (Olokesusi et al., 2015, p. 215). 


\section{Individual and household coping strategies}

Most households in Lagos take some steps to protect themselves against flooding, generally relying on their own resources: $71 \%$ of households surveyed said that they receive no external assistance of any kind, 14\% receive help from family, friends, and community members, $10 \%$ from government agencies, and $5 \%$ from non-governmental organisations, civil society organisations, or religious or community associations (Adelekan, 2016, p. 261). Awareness of flood risk is high, with $68 \%$ of respondents to a 2012 survey across 40 flood-affected districts noting that flooding is not new and describing it as risky (67\%) and potentially disastrous (61\%) (Adelekan \& Asiyanbi, 2016, p. 462). Respondents undertake a wide variety of activities to manage flood risk (Table 5); notably, almost all respondents (94.7\%) claim to undertake "clearing of the immediate environment and ensuring proper disposal of solid waste management', although despite these efforts, the blockage of drainage channels by solid waste remains a major problem (Adelekan, 2016, p. 260).

Table 5: Flood risk management strategies employed by households

\begin{tabular}{l|r}
\hline Strategy & Percentage reporting \\
\hline Waste management/cleaning & $94.7 \%$ \\
\hline Protect unaffected property and survivors & $47.8 \%$ \\
\hline Stay indoors/do nothing & $38.6 \%$ \\
\hline Relocate & $27.5 \%$ \\
\hline Raise the wall/foundation of building & $17.7 \%$ \\
\hline Construction of wooden walkways & $12.1 \%$ \\
\hline Construction of drainage channels & $11.4 \%$ \\
\hline Evacuation of floodwater out of building & $10.2 \%$ \\
\hline Prayer & $8.5 \%$ \\
\hline Community effort & $7.7 \%$ \\
\hline Help ourselves/affected people & $6.1 \%$ \\
\hline Seeking government assistance & $5.7 \%$ \\
\hline Raise funds & $3.6 \%$ \\
\hline Replacement of damaged items & $1.4 \%$ \\
\hline Planting trees & $1.1 \%$ \\
\hline Insure building and property & $0.8 \%$ \\
\hline
\end{tabular}

Source: Adelekan, 2016, p. 261, reproduced with permission

Another survey in five communities across Lagos found different priorities in preparing for floods: $37 \%$ of households said that they used sandbags to protect properties, $31 \%$ raised the entrance to their property, $22 \%$ filled in depressions around the property, and in sharp contrast to the study cited above, only $12 \%$ said they cleared drainage systems (Atufu \& Holt, 2018, p. 88).

Some evidence, however, also points to a fatalistic attitude among some flood-affected residents. In one survey, most households felt that they had only limited ability to influence flood risk: $42 \%$ 'were in strong agreement that they did not have control by means of the resources or capacity to 
protect themselves from their exposure to floods', and only $16 \%$ feeling that they had some level of control over flood risks (Adelekan \& Asiyanbi, 2016, p. 462). Olanrewaju et al. (2019, p. 7) argue that 'the majority of community members do not have coping strategies but take the flood disaster as an act of God that is beyond their control, and all they do thereafter is rebuild their houses and businesses on the same spot'. Another study found that 'direct action by individuals and families, and landlords was taken by $5 \%$ or less of participants... this suggests a resignation to being flooded annually' (Atufu \& Holt, 2018, pp. 87-88).

Most residents do not consider flood risk when choosing where to live, despite being familiar with the prevalence of flooding; instead, factors such as security, privacy, availability, affordability, a lack of choice, proximity to work, or a lack of freedom to choose drove the selection of a place to live (Atufu \& Holt, 2018, p. 85). Other surveys have similarly found that $36 \%$ of respondents felt that their exposure to flooding was unavoidable because they had no choice about where to live (Adelekan \& Asiyanbi, 2016, p. 463), and the desire to acquire property is perceived as more significant than the 'seasonal inconveniences and losses' caused by flooding (Odunuga et al., 2012, pp. 92-93).

\section{Insurance}

Insurance is as an important tool for managing risks associated with natural hazards including flooding. However, residential insurance is 'largely unavailable in low- and middle-income countries' including Nigeria (Adelekan \& Asiyanbi, 2016, p. 465). 'The insurance industry has not played a significant role in flood risk management in Lagos and the country at large... Only multinational corporations and large manufacturing companies and some real estate property owners have been able to benefit from the provisions of insurance in managing flood risk' (Adelekan, 2016, p. 261). Only $0.8 \%$ of respondents to one survey across all local government areas in Lagos had insured buildings and property against flood risk (Adelekan, 2016, p. 261). Lack of insurance disproportionately affects lower-income households and households in informal settlements, making recovery from flooding even more challenging (Adelekan, 2016, p. 257; Atufu \& Holt, 2018, p. 87).

\section{Community-level coping strategies}

Some communities in Lagos have organised initiatives to prepare for and mitigate the effects of flooding. The most common strategies employed include organised sand filling of roads, use of sand bags, building wooden bridges as walkways within the community and clearing drainage channels of solid waste and silt to allow free flow of storm water (Adelekan, 2016, p. 261). In one high-income residential estate on the coast, residents levied fees on themselves at a 'high cost' (the published paper does not report the actual cost) to purchase boulders to protect their properties from storm surges (Adelekan, 2016, p. 261). In some severely-affected communities, community development associations seek assistance from local or state government (Adelekan, 2016, p. 261).

\section{Calabar (Cross River State)}

Calabar (population 600,000), the capital of Cross River State, is built on low-lying terrain on the coast between two large rivers. It is vulnerable to flooding across $65 \%$ of the city due to 
ecosystem degradation which has led to the loss of natural protection provided by mangrove ecosystems, uncontrolled urban development including building on floodplains, inadequate drainage networks and poor solid waste management leading to blocked drainage systems, inadequate drainage facilities, low infiltration due to a high water table and built-up areas with impermeable ground cover, and weak governance systems (Adekola, Lamond, Adelekan, \& Eze, 2020, pp. 841-847; Lamond et al., 2019, p. 4; Lamond \& Adelekan, 2016, p. 789).

\section{Impacts}

Very little information appears to be available about the frequency and impacts of flooding in Calabar. One report notes that 'flooding in Calabar has become an annual occurrence with severe consequences mostly felt by the urban poor' (Adekola et al., 2020, p. 847) but the impacts are not described. Similarly, a survey conducted in 2014 found that $47 \%$ of respondents reported experiencing flooding every year, but no information about the impacts of flooding was collected, apart from respondents being asked whether they felt that flood intensity was 'very high' (59.5\% of respondents chose this answer), 'fairly high' $(40 \%)$, or 'low' $(0.5 \%)$ (Ndoma, 2015, pp. 44-45). During floods, some parts of the city become inaccessible, and some communities have well-established informal routines of using canoes as the principal means of transportation during these times; the city government has also recently purchased boats for use during flood season (Adekola et al., 2020, p. 845). One recent paper reports that in August 2015, a flood in Calabar submerged at least 100 houses and displaced about 400 people (Lamond \& Adelekan, 2016, p. 789).

\section{Risk factors and mitigation efforts ${ }^{6}$}

Urban planning: Rapid and large-scale encroachment of settlements onto low-lying wetland areas without planning permission has increased vulnerability to flooding; in most cases the process of land allocation is informal, with traditional institutions (which managed land before modern formal institutions were introduced) still playing a role and state authorities acting outside the formal (legal) process (Adekola et al., 2020, p. 842). Enforcement of existing planning and zoning laws is weak and there is a general disregard of environmental laws even by state agencies (Adekola et al., 2020, pp. 845-847). Improving collaborative/participative processes and aligning objectives between state and traditional institutions could be a step towards building a common and agreed land allocation framework (Adekola et al., 2020, p. 845).

Drainage systems: One study notes that the existing system drainage system does not flow efficiently by gravity alone and suffers from blockage by sediment as well as solid wastes, and calls for significant redesign of the drainage system using six new drainage channels corresponding to six natural drainage basins in the area (Ugbong \& Budagov, 2016). There have been efforts to channelise the drainage system and to construct underground drains to supplement the existing system (Lamond \& Adelekan, 2016, p. 789), including a reported investment of USD 5.5 million in 2013 in underground drainage systems (Adekola et al., 2020, p. 844). There have also been calls for legislation to prevent construction along storm runoff routes

\footnotetext{
${ }^{6}$ Information in this section taken from Lamond, 2019 refers to stakeholder workshops that were held in Calabar and in Makurdi in 2016. Many of the findings from the workshops in each city are similar, and where that is the case, the findings are repeated in each of the relevant sections of this report.
} 
and to require improved drainage outlets (Antigha et al., 2014, cited in Lamond \& Adelekan, 2016, p. 789).

Solid waste management: As in many other cities across Africa and Asia, the drainage system in Calabar suffers from blockages caused by 'indiscriminate refuse disposal into the drains' (Ugbong \& Budagov, 2016, p. 2). The consumption of sachet water is a particular challenge: where reliable sources of clean water are unavailable, people purchase purified water in sealed plastic sachets to drink, but the empty sachets are often dumped indiscriminately and contribute to the solid waste problem (Adekola et al., 2020, p. 842).

Early warning systems and public awareness: Residents of Calabar rely on government messaging through radio (the most preferred option for $57 \%$ of households and $62 \%$ of businesses), television, and SMS, to get information about moving people and belongings to safety (Lamond et al., 2019, p. 12). State and local governments draw on information from the Nigerian Meteorological Agency, but a local (state level) agency able to process data for early warning could enable better local preparedness (Adekola et al., 2020, p. 847). Participants at the 2016 stakeholder workshop also called for public awareness and sensitisation programmes to educate residents about their actions and impacts on the environment and inform them about flood risk and adaptation opportunities (Adekola et al., 2020, p. 844; Lamond et al., 2019, p. 13).

Institutional structures and coordination: There are no official policies on flood adaptation or management at the state or local government level in Calabar, and no agency with clear responsibility and decision-making powers for flood risk management (Adekola et al., 2020, p. 843). Government agencies have been created to address climate-related hazards including flooding in Calabar, but the result has been fragmented responsibility without provision for coordination or exchange of information, which has 'entrenched bureaucracy and competition', and the concentration of power and resources at the state level tends to leave local governments ill-equipped to deal with flood risk management (Adekola et al., 2020, pp. 845-849). In general, there are no official mechanisms for collaboration and coordination among agencies and with communities, so skills and data are not often shared and communities are rarely consulted; in Calabar, only $17 \%$ of participants in a stakeholder workshop felt that there was 'adequate exchange and interaction among stakeholders' (Adekola et al., 2020, pp. 845, 849; Lamond et al., 2019, p. 8). Recommendations from experts include widening participation in risk management planning, (Lamond et al., 2019, pp. 14-15), reviewing state environmental laws and government agencies to clarify roles and responsibilities including perhaps nominating a lead agency for coordinating flood management (Adekola et al., 2020, p. 851) and bringing flood adaptation actions that are already taking place at the community level into a Calabar Flood Management Plan (Adekola et al., 2020, p. 851).

Institutional capacity building and access to information: In an inter-agency workshop in 2016, stakeholders called for greater access to information and data on climate and weather, geographic and environmental conditions, and socio-economic and demographic conditions to carry out flood risk modelling and feed into adaptation decision-making (Adekola et al., 2020, p. 847; Lamond et al., 2019, p. 8). They also expressed a need to improve agencies' skills and capacities to analyse and use these data across areas such as waste management, drainage and hazards, emergency management and response, forecast and early warning, environmental communication and enlightenment, United Nations frameworks, and solar and clean energy technology (Lamond et al., 2019, p. 8). Suggestions from the workshop included establishing a 
new agency with a mandate to coordinate data and information on risk management, widening participation of stakeholder groups in debates, meetings and consultations, and increasing training for professionals (Lamond et al., 2019, p. 13).

Ecosystem-based initiatives: To increase forest cover in Calabar and across Cross River State, the state government set a target to plant five million trees annually, imposed a two-year logging moratorium, and established an anti-logging task force (Adekola et al., 2020, p. 844).

Enforcement: Participants in a multi-agency workshop in 2016 ranked the need to do more in law enforcement as the most important of all flood adaptation strategies, ahead of structural, institutional and societal approaches (Adekola et al., 2020, p. 846). Participants also 'complained of shoddy engineering and drainage projects procured by government agencies', which was blamed not on corruption but on politics (Adekola et al., 2020, p. 847). To avoid political pressures and conflicts of interest, one suggestion made was to empower a network of stakeholders to enforce environmental laws, rather than relying on an enforcement body controlled by the state (Adekola et al., 2020, p. 847). In 2016, Cross River State created a statelevel agency (originally called 'Green Police' but renamed 'Green Sheriff' following objections from the national police force) to enforce state environmental laws, but according to recent news reports, 'this organisation is only on paper, with some customised vehicles being used by a joint patrol team of the police, army and navy occasionally... the group is not really visible or effective' (Akpan, Godwin, \& Egbejule, 2020).

Individual and community-level coping strategies: Common strategies practiced by residents and businesses for flood protection include elevating buildings, constructing concrete walls, and installing flood boards (Figure 1) (Adekola et al., 2020, p. 845; Lamond et al., 2019, p. 12). Some communities coordinate 'annual purchase and laying of sandbags at the onset of flood season', sometimes with support from NGOs and local businesses (Adekola et al., 2020, p. 845). In general, however, community capital and community-based resilience is low: 'individuals take actions but do not appear to be able to rely on others for help or support; more respondents would rely on prayer than on their neighbours' (Lamond et al., 2019, p. 12). Ecosystem-based solutions and behavioural adaptation 'are not selected as preferred approaches to adaptation by respondents, but planting trees was seen as a helpful strategy for flooding' (Lamond et al., 2019, p. 12). NGOs and the private sector 'play voluntary, fragmented and uncoordinated roles' in supporting community resilience (Adekola et al., 2020, p. 845). 
Figure 1: Flood adaptation actions in Calabar: percentage of respondents who have adopted or would adopt actions in advance of flood

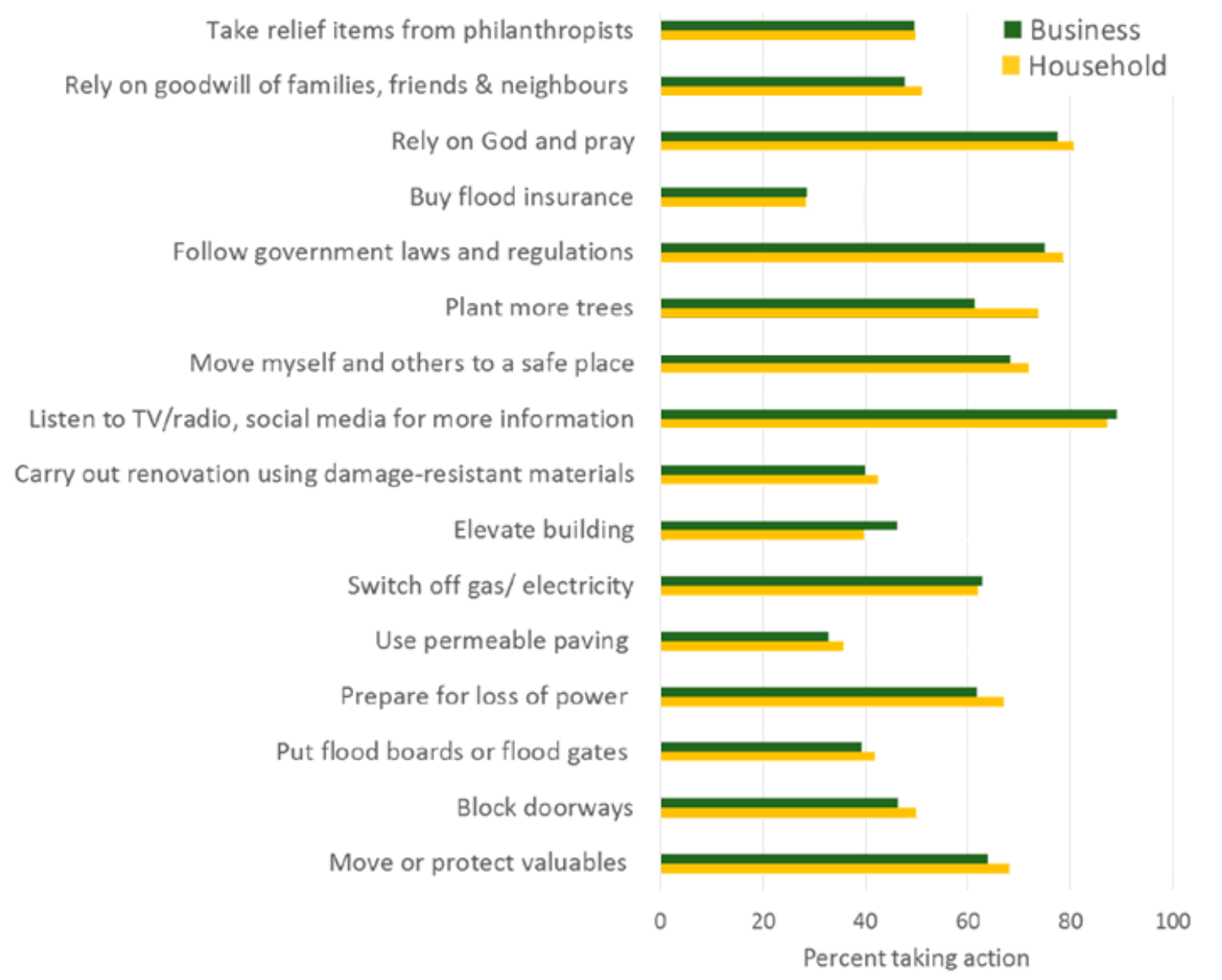

Adapted from Lamond et al., 2019, p. 13. Licensed used under Creative Commons Attribution (CC BY 4.0)

\section{Makurdi (Benue State)}

Makurdi (population 500,000), the capital of Benue State, is located on the Benue River and most parts of the city are built on low-lying, impermeable soils, making the city susceptible to annual flooding especially at the peak of the rainy season (Lamond, Adekola, Adelekan, Eze, Bhattacharaya-Mis, \& Ujoh, 2018, pp. 52-53; Lamond et al., 2019, p. 4). Drivers of flooding include uncontrolled urban development, inadequate drainage networks that are poorly maintained, dumping of solid wastes in drainage and water channels, low infiltration due to a high water table and the spread of built-up areas with impermeable ground cover, encroachment on water channels, lack of local knowledge and flood education, river channel siltation, and changes in vegetation and the clearing of forest cover (Lamond \& Adelekan, 2016, p. 790).

\section{Impacts}

Very little information appears to be available about the frequency and impacts of flooding in Makurdi. One report notes that 'flooding has become an annual event resulting to loss and destruction of properties worth millions of naira' [tens of thousands of US dollars] (Shabu \& Tyonum, 2013, p. 121) but does not quantify the impacts more precisely. A survey of residents 
conducted in 2012 reported their perceptions of the principal effects of flooding in Makurdi as including loss of lives and personal property (42\%), facilitating the spread of pests and diseases (20\%), inundation generally (10\%), destruction of housing (17\%), destruction of roads $(8 \%)$, and release of toxic materials (4\%) (Shabu \& Tyonum, 2013, p. 123) but did not attempt to estimate the magnitude of these impacts. News media reported that in 2011, 'over 300 houses in Makurdi were flooded as a result of heavy downpour which destroyed properties and rendered many homeless.' (Shabu \& Tyonum, 2013, p. 121). In September 2012, the sudden release of water from a dam caused flooding that affected 33,000 people, displaced 189 people, and killed one person, with an unspecified number of houses 'submerged' (Federal Government of Nigeria, 2013, p. 123).

\section{Risk factors and mitigation efforts ${ }^{7}$}

Urban planning and growth: Makurdi's growth, especially since 1976, has not been based on a comprehensive land use plan and has resulted in most neighbourhoods being situated on lowlying impermeable soils (Lamond \& Adelekan, 2016, p. 790). The use of flood plains for urban development, changes in land cover, and destruction of mangroves in coastal areas have all contributed to flood risk (Ndoma, 2015, and Antigha et al., 2014, cited in Lamond et al., 2019, p. 4). Major challenges for the local government are 'people erecting unapproved building specifications, deliberately increasing land allocation, and acquiring land through customary means rather than formally through government agencies (Lamond et al., 2018, p. 62). A recent news media report counted at least 193 illegal building constructed on nine of the eleven water channels running across Makurdi (Channels Television, 2017, cited in Lamond et al., 2018, p. $62)$.

Drainage systems: The drainage system in Makurdi is poorly designed, with many drains too narrow and shallow, and has been poorly maintained and blocked by silt and solid waste. Some participants at a stakeholder workshop in 2016 suggested that corruption may have led to drainage being under-designed or not constructed to specification (Lamond et al., 2018, p. 61).

Solid waste management: As is the case in other cities, solid wastes are often dumped into drainage systems in Makurdi, leading to blocked drains and flooding (Lamond et al., 2018, p. 61).

Early warning systems and public awareness campaigns: Residents of Makurdi rely on the government messaging through radio (the most preferred option for $79 \%$ of households and $78 \%$ of businesses), television, and SMS to get information about moving people and belongings to safety (Lamond et al., 2019, p. 12). Participants at the 2016 stakeholder workshop also called for public awareness and sensitisation programmes to educate residents about their actions and impacts on the environment and inform them about flood risk and adaptation opportunities (Lamond et al., 2019, p. 13).

Institutional structures and coordination: In general, there are no official mechanisms for collaboration and coordination among agencies and with communities, so skills and data are not often shared and communities are rarely consulted; in Makurdi, only $17 \%$ of participants in a

\footnotetext{
7 Information in this section taken from Lamond, 2019 refers to stakeholder workshops that were held in Calabar and in Makurdi in 2016. Many of the findings from the workshops in each city are similar, and where that is the case, the findings are repeated in each of the relevant sections of this report.
} 
stakeholder workshop felt that there was 'adequate exchange and interaction among stakeholders' (Lamond et al., 2019, p. 8). Recommendations from experts include widening participation in risk management planning (Lamond et al., 2019, pp. 14-15).

Institutional capacity building and access to information: In an inter-agency workshop in 2016, stakeholders called for greater access to information and data on climate and weather, geographic and environmental conditions, and socio-economic and demographic conditions to carry out flood risk modelling and feed into adaptation decision-making (Lamond et al., 2019, p. 8). They also expressed a need to improve agencies' skills and capacities to analyse and use these data across areas such as waste management, drainage and hazards, emergency management and response, forecast and early warning, environmental communication and enlightenment, United Nations frameworks, and solar and clean energy technology (Lamond et al., 2019, p. 8). Suggestions from the workshop included establishing a new agency with a mandate to coordinate data and information on risk management, widening participation of stakeholder groups in debates, meetings and consultations, and increasing training for professionals (Lamond et al., 2019, p. 13).

Individual and community-level coping strategies: In a survey conducted in 2012, residents of Makurdi stated that their principal coping strategies included clearing blocked drains (26\%), creating drainage channels (33\%), using sand banks (19\%), using sandbags (9\%), fumigating stagnant flood waters (2\%), and 'face-to-face awareness of flooding' (1\%); however, $56 \%$ of respondents stated that the strategies they adopted were 'not very effective' (Shabu \& Tyonum, 2013 , p. 125). A more recent stakeholder workshop held in 2016 found that common strategies practiced by residents and businesses for flood protection include elevating buildings, constructing concrete walls, and installing flood boards (Figure 2) (Lamond et al., 2019, p. 12). In general, however, community capital and community-based resilience is low: 'individuals take actions but do not appear to be able to rely on others for help or support; more respondents would rely on prayer than on their neighbours' (Lamond et al., 2019, p. 12). Ecosystem-based solutions and behavioural adaptation 'are not selected as preferred approaches to adaptation by respondents, but planting trees was seen as a helpful strategy for flooding' (Lamond et al., 2019, p. 12). 
Figure 2: Flood adaptation actions in Makurdi: percentage of respondents who have adopted or would adopt actions in advance of flood

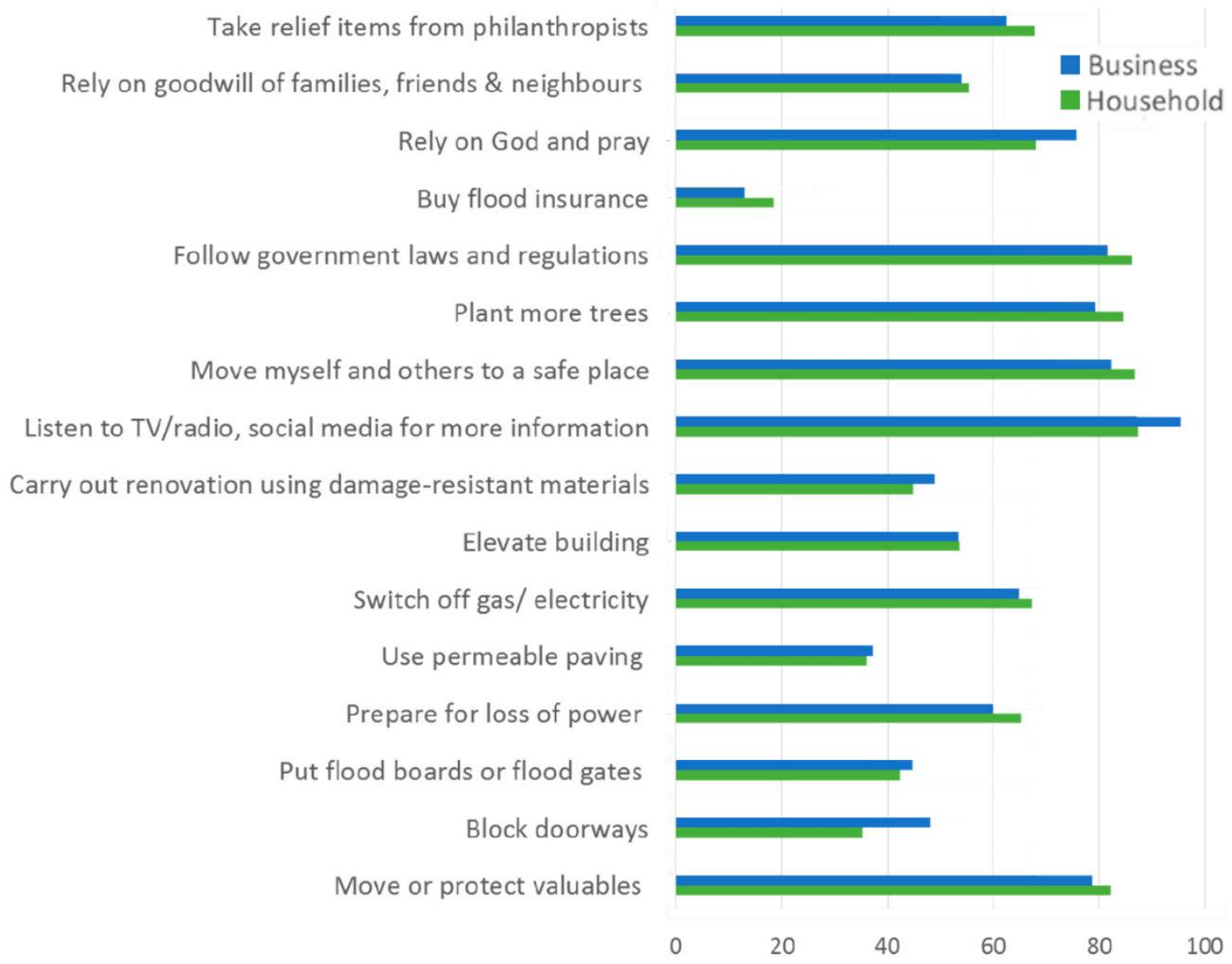

Adapted from Lamond et al., 2019, p. 13. Licensed used under Creative Commons Attribution (CC BY 4.0).

Despite the risk of flooding, 'residents of flood affected areas continue to live in these areas because of lack of alternatives, cultural affinity, family ties, nature of occupation, and availability of cheaper houses to rent' (Ocheri \& Okele, 2012, cited in Lamond \& Adelekan, 2016, p. 790). Similarly, a survey of residents of Makurdi in 2014 that asked why they remain in flood-prone areas found that $33 \%$ of respondents claimed they had no alternative, $19 \%$ cited the low cost of land and housing in their current location, $13 \%$ said they had stayed in the area for a long time, $12 \%$ cited a desire to maintain ties with family and friends, $11 \%$ mentioned proximity to work, $8 \%$ mentioned lack of crowding, and 6\% were undecided (Ahile \& Andltyavyar, 2014, p. 4)

\section{Ibadan (Oyo State)}

Ibadan (population 3 million), the capital of Oyo State, is highly exposed to frequent flooding, particularly in crowded and poor residential districts that have developed in low-lying areas (Adelekan, 2020, p. 214; World Bank, 2014, pp. 4-5, 7). The principal drivers of flood risk in Ibadan are uncontrolled urban development on floodplains and wetland areas, an inadequate drainage system with narrow culverts and bridges, dumping of solid waste in drainage channels, growth of vegetation along river channels a weak institutional framework for flood risk management with inadequate organisational capacities and coordination, and limited 
understanding and awareness of flood risk in the city (Agbola, Ajayi, Taiwo, \& Wahab, 2012; Egbinola, Olaniran, \& Amanambu, 2017; World Bank, 2014).

\section{Impacts}

Floods are a common occurrence in Ibadan and have been officially recorded since 1951, but records 'are patchy and characterized by incomplete information' (Agbola et al., 2012, p. 207). There are 'large gaps' in data on risk, in particular a lack of consistent, comparable, accessible, and high quality data on deaths, injuries, and damage arising from natural hazards of all types including flooding (Adelekan, 2020, p. 216). By collecting data from multiple sources including newspaper articles, Adelekan (2020) estimates that 129 people were killed, 9,112 houses were damaged, and 3,102 houses were destroyed by flooding in Ibadan from 2000-2015.

The World Bank has estimated, extrapolating from floods that occurred in 2011 as a basis, that Ibadan experiences average annual losses of USD 105.3 million per year (World Bank, 2014, p. 86).

Floods in 2011 led to the deaths of between 102 and 120 people and 'submerged or washed away' 2,105 buildings, with estimates of total damage to property ranging between NGN 30 and more than 100 billion (USD 190 to 635 million) (Agbola et al., 2012, pp. 207-208; Egbinola et al., 2017, p. 549; Federal Government of Nigeria, 2013, p. 77; Oladokun \& Proverbs, 2016, p. 486; World Bank, 2014, p. 35). Roads were made impassable, bridges and culverts were damaged, electricity supplies were disrupted in some neighbourhoods, and damage to the Eleiyele Dam led to more than a year of disruption to water services (Agbola et al., 2012, p. 215). The University of Ibadan suffered NGN 10 billion (USD 63 million) in damage to buildings and equipment (Agbola et al., 2012, p. 215). Twelve percent of respondents to a survey in 2011 claimed that floodwater entered their shops and spoiled goods or equipment, and losses of farm animals and fish ponds amounted to hundreds of millions of naira (millions of dollars) (Agbola et al., 2012, p. 216).

In a survey carried out in flood-affected areas of Ibadan in 2013, respondents described the effects of flooding (not necessarily impacts they themselves had experienced, but impacts that they were aware of) as including destruction of contents of houses (96\%), loss of sources of livelihood (72\%), people becoming homeless (59\%), deaths (55\%), trauma (45\%), pollution of wells and other water sources (36\%), health problems (30\%), and damage to buildings (27\%) (Egbinola et al., 2017, p. 549).

In a different survey, respondents who were asked why they stayed in locations that they knew to be at risk of flooding cited the high cost of rent, unemployment, underemployment, and uncertainty in the economy as compelling them to remain in their present locations" (Agbola et al., 2012, p. 216).

\section{Risk factors and mitigation efforts}

Urban planning: Like other cities in Nigeria, Ibadan has struggled to control urban development on floodplains and wetland areas. Developments have been built within the legal setback limits of most rivers and streams in Ibadan, and the Oyo State Government estimated in 2011 that there were 26,553 buildings within the approved statutory setback limits (Egbinola et al., 2017, p. 551). Some rivers and streams in lbadan have been narrowed or diverted with land reclaimed for buildings, and floodplains have been filled in to be used for buildings, which increases flood risk 
to other low-lying areas (Agbola et al., 2012, p. 213). Another impact of urbanisation is increasing the coverage of land with impervious surfaces which prevent floodwater from infiltrating into the ground; existing building regulations are often overlooked or ignored (Agbola et al., 2012, p. 214). The state government has sought to remove structures that have been built along river channels and floodplains which obstruct natural flow paths of rainwater, but with limited success. After the 2011 floods, more than 1,000 houses obstructing floodwater flow were identified for demolition, but 'due to pressure from landlords and landlord associations, and pending litigations filled by owners of some structures, the government ended up demolishing only 56 houses (Egbinola et al., 2017, p. 552). Deforestation has also been a significant factor contributing to flood risk, and wetlands, agricultural areas, and forested areas in and around lbadan which formerly served as storage areas for floodwater and permitted water to infiltrate into the soil have been built upon, increasing runoff (Agbola et al., 2012, p. 214).

Drainage systems: Most of the city's bridges and culverts were built in the 1960s and although adequate at the time, increased urbanisation has increased the volume of flood flows which now exceed capacity (Agbola et al., 2012, p. 211; Egbinola et al., 2017, p. 551). Lack of maintenance, blockage by debris and solid waste, and uncontrolled vegetation growth decrease the capacity of natural and artificial drainage channels, bridges, and culverts (Agbola et al., 2012, p. 211; Egbinola et al., 2017, p. 551; World Bank, 2014, p. 37). It has been reported that only about $20 \%$ of the city has a functioning storm water drainage network (World Bank, 2014, p. 37).

Channelisation of the Ogunpa River, which began in 1977, 'has virtually put a stop to the incidences of flooding along the channel' in areas where work has been completed, although major floods occur in areas that have not been channelised (Egbinola et al., 2017, p. 551). Other channelisation work is underway (as of 2017) on the Awba Stream, and the state government is working to construct street drainage channels in areas affected by flash floods (Egbinola et al., 2017, p. 552). River channels have also been dredged by the State and local governments, but no information appears to be available to indicate how effective this has been, and some local residents have argued that the dredging has not been deep enough (Egbinola et al., 2017, p. 552).

Solid waste management: Drainage channels are frequently used to dispose of solid waste, especially in low-income neighbourhoods where there is no government waste collection service and residents either cannot afford to pay private waste collectors or have been unable to organise this at the community level (Agbola et al., 2012, p. 211; Egbinola et al., 2017, pp. 550551). Residents dump waste in drainage channels early in the morning, late at night, and especially before and during rainfall events in the belief that the rainwater will wash the materials away; instead, they impede flow and become trapped at bridges and culverts, causing flooding (Agbola et al., 2012, p. 211; Egbinola et al., 2017, pp. 550-551). The Oyo State government has made efforts to expand waste collection services, provide more refuse bins, and advertise on radio and television to encourage better waste disposal practices (Egbinola et al., 2017, p. 552).

Institutional capacity and coordination: The World Bank in 2014 noted that flood risk management capacity in Ibadan is fragmented across various ministries, departments, and agencies, 'state and local governments are ill-prepared to address flood incidents and attempts to control flood risk have generally been unsuccessful', and that the relevant organisations suffer from weak institutional capacity, insufficiently clear responsibilities and mandates, and poor coordination (World Bank, 2014, p. 37). An absence of policies on river and stream management contributed to the degradation of drainage systems (Agbola et al., 2012, p. 211), the absence of 
an integrated urban planning and management framework contributed to the growth of settlements in flood-prone areas (World Bank, 2014, p. 36).

Public awareness and early warning: In 2011, a lack of precise and specific early warnings was a contributing factor to the high number of fatalities. Radio stations reported the possibility of heavy rainfall, but not details about when to expect flooding and what steps people should take to prepare; only one radio station out of the six in the city broadcast specific warnings about flooding (Agbola et al., 2012, p. 214). A survey of lbadan residents also identified an absence of data and information from government and other agencies on flood hazard and vulnerability across the city as a challenge for guiding urban development and assisting people in flood preparedness (Agbola et al., 2012, p. 212). The World Bank noted that there was a general lack of awareness among residents about environmental laws and factors contributing to floods including the risks associated with building on flood plains (World Bank, 2014, p. 36), and that the State Emergency Management Agency had limited capacity for carrying out early warning and emergency preparedness and response work (World Bank, 2014, p. 36).

Residents' perceptions of flood risk: Surveys undertaken in 2011 and 2013 by different researchers found that residents in both cases perceived building too close to waterways, inadequate drainage facilities, and dumping solid waste in drainage channels as the principal causes of flooding, apart from the proximate cause of heavy rainfall (Agbola et al., 2012, p. 210; Egbinola et al., 2017, p. 550). 
Table 6: Perceived causes of flooding in surveys of lbadan residents, 2011 and 2012

\begin{tabular}{|c|c|}
\hline \multicolumn{2}{|c|}{$\begin{array}{l}\text { Perceived causes of flooding } \\
\text { (2011 survey) }\end{array}$} \\
\hline Building close to riverbanks & $89 \%$ \\
\hline $\begin{array}{l}\text { Changing the course of rivers by } \\
\text { development }\end{array}$ & $83 \%$ \\
\hline $\begin{array}{l}\text { Dumping refuse in drainage } \\
\text { channels }\end{array}$ & $74 \%$ \\
\hline Ignorance of flood risk & $70 \%$ \\
\hline Lack of early warning information & $53 \%$ \\
\hline $\begin{array}{l}\text { River channels being covered by } \\
\text { weeds }\end{array}$ & $52 \%$ \\
\hline Deforestation & $39 \%$ \\
\hline $\begin{array}{l}\text { Inadequate monitoring of housing } \\
\text { development }\end{array}$ & $31 \%$ \\
\hline Riverbed sedimentation & $24 \%$ \\
\hline Increased impervious surfaces & $9 \%$ \\
\hline Heavy rainfall & $95 \%$ \\
\hline Dam breaking & $10 \%$ \\
\hline
\end{tabular}

\begin{tabular}{|c|c|}
\hline \multicolumn{2}{|c|}{$\begin{array}{l}\text { Perceived causes of flooding } \\
\text { (2013 survey) }\end{array}$} \\
\hline $\begin{array}{l}\text { Dumping refuse in stream } \\
\text { channels }\end{array}$ & $88 \%$ \\
\hline $\begin{array}{l}\text { Drainage channels being too } \\
\text { shallow or blocked by sediment }\end{array}$ & $86 \%$ \\
\hline $\begin{array}{l}\text { Culverts/bridge throughways not } \\
\text { wide enough }\end{array}$ & $71 \%$ \\
\hline $\begin{array}{l}\text { Houses built too close to stream } \\
\text { channels }\end{array}$ & $53 \%$ \\
\hline $\begin{array}{l}\text { Growth of vegetation on river } \\
\text { channels }\end{array}$ & $49 \%$ \\
\hline $\begin{array}{l}\text { Blockage of culverts and bridge } \\
\text { throughways }\end{array}$ & $31 \%$ \\
\hline $\begin{array}{l}\text { Increased impervious } \\
\text { surfaces/urbanisation }\end{array}$ & $28 \%$ \\
\hline Heavy/prolonged rainfall & $94 \%$ \\
\hline $\begin{array}{l}\text { Source: Egbinola et al., 2017, p. 550, rep } \\
\text { permission. }\end{array}$ & ed with \\
\hline
\end{tabular}

Ibadan Urban Flood Management Project: The Ibadan Urban Flood Management Project, funded by the World Bank until 2022, recognises the need for a long-term, integrated approach to flood risk management (Oladokun \& Proverbs, 2016, p. 486) and is made up of three components: (1) flood risk identification, prevention, and preparedness measures including the development of strategic plans and feasibility studies (USD 43 million); (2) flood risk reduction measures including rehabilitation of drains, culverts, roads, and dams, upgrading critical public infrastructure (USD 149 million); and (3) project administration and management support (USD 28 million) (World Bank, 2014, pp. 9-10). These measures are expected to reduce average annual losses significantly: the early warning system is expected to reduce losses by $5 \%$ (USD 5.3 million) per year, improvements to critical infrastructure 18\% (USD 19.4 million), reductions in runoff from upper catchment areas 14\% (USD 15.3 million), and improvements to urban drainage are expected to reduce average annual losses by 42\% (USD 44.6 million) (World Bank, 2014, p. 21). Some of these benefits overlap and are not cumulative, so the total benefit from implementing all of these measures is $52 \%$ or USD 55.0 million (World Bank, 2014, p. 21). 


\section{References}

Adekola, O., Lamond, J., Adelekan, I., \& Eze, E. B. (2020). Evaluating flood adaptation governance in the city of Calabar, Nigeria. Climate and Development, 12(9), 840-853.

https://doi.org/10.1080/17565529.2019.1700771

Adelekan, I. O. (2010). Vulnerability of poor urban coastal communities to flooding in Lagos, Nigeria. Environment and Urbanization, 22(2), 433-450. https://doi.org/10.1177/0956247810380141

Adelekan, I. O. (2016). Flood risk management in the coastal city of Lagos, Nigeria. Journal of Flood Risk Management, 9(3), 255-264. https://doi.org/10.1111/jfr3.12179

Adelekan, I. O. (2020). Urban dynamics, everyday hazards and disaster risks in Ibadan, Nigeria. Environment and Urbanization, 32(1), 213-232. https://doi.org/10.1177/0956247819844738

Adelekan, I. O., \& Asiyanbi, A. P. (2016). Flood risk perception in flood-affected communities in Lagos, Nigeria. Natural Hazards, 80(1), 445-469. https://doi.org/10.1007/s11069-015-1977-2

Agbola, B. S., Ajayi, O., Taiwo, O. J., \& Wahab, B. W. (2012). The August 2011 flood in Ibadan, Nigeria: Anthropogenic causes and consequences. International Journal of Disaster Risk Science, 3(4), 207-217. https://doi.org/10.1007/s13753-012-0021-3

Ahile, S. I., \& Andltyavyar, E. M. (2014). Household Perception and Preparedness Against Flooding in Makurdi Town, Benue State, Nigeria. IOSR Journal of Environmental Science, Toxicology and Food Technology, 8(11).

https://www.academia.edu/10367053/Household_Perception_and_Preparednessagainst_Floodi ng_in_Makurdi_Town_Benue_State_Nigeria

Ajibade, I., McBean, G., \& Bezner-Kerr, R. (2013). Urban flooding in Lagos, Nigeria: Patterns of vulnerability and resilience among women. Global Environmental Change, 23(6), 1714-1725. https://doi.org/10.1016/j.gloenvcha.2013.08.009

Akinwotu, E. (2019, July). Waves of change: Nigeria's Lagos battles Atlantic erosion. Phys.Org. https://phys.org/news/2019-07-nigeria-lagos-atlantic-erosion.html

Akpan, A., Godwin, A., \& Egbejule, M. (2020, December 16). As centralised policing fails, SouthSouth leaders consider alternative models. The Guardian. https://guardian.ng/politics/ascentralised-policing-fails-south-south-leaders-consider-alternative-models/

Atufu, C. E., \& Holt, C. P. (2018). Evaluating the impacts of flooding on the residents of Lagos, Nigeria. In S. Hernández, S. Mambretti, D. Proverbs, \& J. Puertas (Eds.), Urban Water Systems \& Floods II (Vol. 184, pp. 81-90). WIT Press. https://doi.org/10.2495/FRIAR180081

Croitoru, L., Miranda, J. J., Khattabi, A., \& Lee, J. J. (2020). The cost of coastal zone degradation in Nigeria: cross River, Delta and Lagos States. World Bank Group. https://openknowledge.worldbank.org/handle/10986/34758

Egbinola, C. N., Olaniran, H. D., \& Amanambu, A. C. (2017). Flood management in cities of developing countries: the example of Ibadan, Nigeria. Journal of Flood Risk Management, 10(4), 546-554. https://doi.org/10.1111/jfr3.12157

Eko Atlantic. (n.d.). The History of the Great Wall of Lagos. Eko Atlantic. https://www.ekoatlantic.com/education/sea-wall/

Federal Government of Nigeria. (2013). Nigeria Post-Disaster Needs Assessment (PDNA). Federal Government of Nigeria.

https://www.humanitarianresponse.info/sites/www.humanitarianresponse.info/files/assessments/ 23052013_nga_post_disaster_needs_assessment_2012_floods.pdf 
Haider, H. (2019). Climate change in Nigeria: Impacts and responses. Institute of Development Studies. https://opendocs.ids.ac.uk/opendocs/handle/20.500.12413/14761

IFRC. (2011). Nigeria: Flash Floods. International Federation of Red Cross and Red Crescent Societies. https://www.ifrc.org/docs/appeals/11/MDRNG010.pdf

Lagos Bureau of Statistics. (2016). Household Survey 2016. Lagos State Government. http://mepb.lagosstate.gov.ng/wp-content/uploads/sites/29/2020/08/House-Hold-REPORTY2016.pdf

Lagos State Government. (2021). About Lagos. Lagos State Government. https://lagosstate.gov.ng/about-lagos/

Lamond, J., Adekola, O., Adelekan, I., Eze, B., \& Ujoh, F. (2019). Information for Adaptation and Response to Flooding, Multi-Stakeholder Perspectives in Nigeria. Climate, 7(4), 46. https://doi.org/10.3390/cli7040046

Lamond, J., Adekola, O., Adelekan, I., Eze, E. B., Bhattacharaya-Mis, N., \& Ujoh, F. (2018). Adaptation of urban infrastructure to enhance climate resilience in Nigeria. ICF International.

Lamond, J., \& Adelekan, I. (2016). Mitigation of climate risks through adaptation and urban management in Nigerian cities. In P. T. Costa, D. Quino, \& R. A. C. Garcia (Eds.), International Conference on Urban Risks. Centro Europeu de Riscos Urbanos (CERU). http://www.cerueuropa.pt/icur2016/ICUR2016_Proceedings.pdf

National Emergency Management Agency. (2020). Update on Flood 2020 Response. National Emergency Management Agency. https://nema.gov.ng/flood-updates/

Ndoma, E. E. (2015). Effectiveness of Drainage Networks on Floods in Calabar Metropolis, Nigeria [Ahmadu Bello University]. http://kubanni.abu.edu.ng/jspui/bitstream/123456789/6974/1/EFFECTIVENESS OF DRAINAGE NETWORKS ON FLOODS IN CALABAR METROPOLIS\%2C NIGERIA.pdf

Nkwunonwo, U. C., Whitworth, M., \& Baily, B. (2016). Review article: A review and critical analysis of the efforts towards urban flood risk management in the Lagos region of Nigeria. Natural Hazards and Earth System Sciences, 16(2), 349-369. https://doi.org/10.5194/nhess-16-349-2016

Odunuga, S., Oyebande, L., \& Omojola, A. S. (2012). Social-Economic Indicators and Public Perception on Urban Flooding in Lagos, Nigeria. Hydrology for Disaster Management. https://silo.tips/download/social-economic-indicators-and-public-perception-on-urban-flooding-inlagos-nige

Ogunsote, O. O., Adedeji, Y., \& Ogunsote, B. P. (2011). Combating Environmental Degradation through Sustainable Landscaping in Emerging Mega Cities: A Case Study of Lagos, Nigeria. Proceedings of the 24th World Congress of Architecture. https://www.academia.edu/2951276/Combating_Environmental_Degradation_through_Sustaina ble_Landscaping_in_Emerging_Mega_Cities_A_Case_Study_of_Lagos_Nigeria

Oladokun, V. O., \& Proverbs, D. (2016). Flood risk management in Nigeria: a review of the challenges and opportunities. International Journal of Safety and Security Engineering, 6(3), 485-497. https://doi.org/10.2495/SAFE-V6-N3-485-497

Olanrewaju, C. C., Chitakira, M., Olanrewaju, O. O., \& Louw, E. (2019). Impacts of flood disasters in Nigeria: A critical evaluation of health implications and management. Jàmbá: Journal of Disaster Risk Studies, 11(1). https://doi.org/10.4102/jamba.v11i1.557

Olokesusi, F., Olorunfemi, F. B., Onwuemele, A., \& Oke, M. O. (2015). Awareness of and Responses to the 2011 Flood Warnings Among Vulnerable Communities in Lagos, Nigeria. In B. Werlen (Ed.), Global Sustainability: Cultural Perspectives and Challenges for Transdisciplinary 
Integrated Research (pp. 203-223). Springer International Publishing. https://doi.org/10.1007/978-3-319-16477-9_11

Ouikotan, R. B., van der Kwast, J., Mynett, A., \& Afouda, A. (2017). Gaps and challenges of flood risk management in West African coastal cities. XVI World Water Congress.

https://iwra.org/member/congress/resource/ABSID329_ABSID329_full_paper.pdf

Shabu, T., \& Tyonum, T. E. (2013). Residents Coping Measures in Flood Prone Areas of Makurdi Town, Benue State. Applied Ecology and Environmental Sciences, 1(6), 120-125. https://doi.org/10.12691/aees-1-6-4

Sojobi, A. O., Balogun, I. I., \& Salami, A. W. (2016). Climate change in Lagos state, Nigeria: what really changed? Environmental Monitoring and Assessment, 188(10), 556.

https://doi.org/10.1007/s10661-016-5549-z

Ugbong, I., \& Budagov, I. (2016). FORMULATING AN OPTIMAL DRAINAGE MODEL FOR THE CALABAR AREA USING CARTOGRAPHIC TECHNIQUES. Journal of Ecological Engineering, 17(1), 1-9. https://doi.org/10.12911/22998993/61183

World Bank. (2014). Project Appraisal Document on a Proposed Credit in the Amount of SDR 129.1 Million (US\$200 Million Equivalent) to the Federal Republic of Nigeria for the Ibadan Flood Management Project. World Bank.

http://documents 1.worldbank.org/curated/en/536881468144274402/pdf/PAD6780PAD0P13010 Box385224B00OUO090.pdf

\section{Suggested citation}

Lucas, B. (2021). Urban flood management in Nigeria. K4D Helpdesk Report 948. Brighton, UK: Institute of Development Studies. DOI: 10.19088/K4D.2021.018

\section{About this report}

This report is based on six days of desk-based research. The K4D research helpdesk provides rapid syntheses of a selection of recent relevant literature and international expert thinking in response to specific questions relating to international development. For any enquiries, contact helpdesk@k4d.info.

K4D services are provided by a consortium of leading organisations working in international development, led by the Institute of Development Studies (IDS), with Education Development Trust, Itad, University of Leeds Nuffield Centre for International Health and Development, Liverpool School of Tropical Medicine (LSTM), University of Birmingham International Development Department (IDD) and the University of Manchester Humanitarian and Conflict Response Institute (HCRI).

This report was prepared for the UK Government's Foreign, Commonwealth and Development Office (FCDO) and its partners in support of pro-poor programmes. Except where otherwise stated, it is licensed for non-commercial purposes under the terms of the Open Government Licence v3.0. K4D cannot be held responsible for errors, omissions or any consequences arising from the use of information contained in this report. Any views and opinions expressed do not necessarily reflect those of FCDO, K4D or any other contributing organisation.

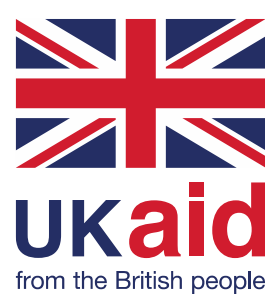

(C) Crown copyright 2021 